Understanding entrepreneurial opportunities through metaphors: A narrative approach to theorising family entrepreneurship

Allan Discua Cruz ${ }^{* \#}$, and Eleanor Hamilton ${ }^{*}$, and Sarah Jack ${ }^{* \dagger}$

* Department of Entrepreneurship and Strategy, Lancaster University Management School, Lancaster, LA14YX, United Kingdom.

${ }^{\dagger}$ Jacob and Marcus Wallenberg Centre for Innovative and Sustainable Business Development, House of Innovation, Stockholm School of Economics, Box 650, SE-113 83 Stockholm, Sweden.

${ }^{\#}$ Corresponding author: Tel +441524510722. Email: a.discuacruz@lancaster.ac.uk 


\section{Understanding entrepreneurial opportunities through metaphors: A narrative approach to theorising family entrepreneurship}

The concept of opportunity is central to entrepreneurship theory. This article contributes to theorising family entrepreneurship across generations by examining how entrepreneurial opportunities are constructed, communicated, and acted upon at the intersection between family and business. Drawing on the experiences of four families in different business sectors in Honduras, the study adopts a narrative perspective and argues that metaphors of entrepreneurial opportunity can enrich our understanding of family entrepreneurship. Findings also suggest that metaphors play a role in developing entrepreneurial legacy. This study of metaphors of opportunity, and how they might entail entrepreneurial legacy, opens up new avenues for theorising intergenerational family entrepreneurship. In examining the metaphors referring to entrepreneurial practices developed and repeated in the family, this study contributes to understanding family entrepreneurship as a social and discursive process where meanings and values are communicated and maintained in everyday interactions.

Keywords: Family Entrepreneurship; Entrepreneurial Opportunity; Narratives; Metaphor

\section{Introduction}

This study responds to calls to advance the field of family entrepreneurship by extending knowledge on the intersection where entrepreneurship and family meet (Randerson et al. 2015a, 144). A significant process for an entrepreneurial family is the creation of new opportunities. In constructing an entrepreneurial opportunity (Anderson 2000; Randerson, Degeorge, and Fayolle 2015b), family members often face unfamiliar and uncharted territories, thus making sense of their journey through narratives embedded in family discourse (Hamilton 2013). However, we know little about how such narratives are constructed or used in family 
entrepreneurship. As such, this study explores how metaphors provide a medium for a shared understanding of opportunities, and how this influences family entrepreneurship.

A metaphor is the use of a familiar image to illuminate an unfamiliar idea or institution (Clarke, Holt, and Blundel 2014; Cornelissen 2005). As a linguistic and cognitive device, it bridges diverse elements or domains by framing the unfamiliar in terms of the familiar to make its understanding easier (Lakoff and Johnson 1980). Whilst metaphors are increasingly recognised as important in entrepreneurship research (Dodd, Jack, and Anderson 2013; Gaddefors 2007; Dodd 2002), little is known about how entrepreneurial families use metaphors to understand and construct entrepreneurial opportunities and enact family entrepreneurship (Larty and Hamilton 2011; Hamilton 2013; Hamilton, Discua Cruz, and Jack 2017).

In this study, we focus on metaphors that entrepreneurial families use when they talk about entrepreneurial opportunities. We offer a qualitative longitudinal study that adopts a narrative approach to understand the way entrepreneurial families turn shared experiences into metaphors to shape how they interpret opportunities over time (Hamilton et al. 2017). We also draw on social systems theory as a way to build appreciation of communicative processes for family entrepreneurship (von Schlippe and Frank 2013).

This study contributes to the field of family entrepreneurship by analysing the role of family discourse in constructing and developing entrepreneurial opportunities, thereby addressing important questions at the micro-level of the intersection between family and entrepreneurship (Randerson et al. 2015a). Further, it shows how entrepreneurial opportunities are constructed through metaphors, and how the family and entrepreneurship domain intersect in the creation of opportunities and the development of family entrepreneurship. Considering opportunity in terms of family entrepreneurship and how this entails the continuous development of opportunities within and across generations, the study demonstrates that family entrepreneurship narratives rely on old, well-worn metaphors, sustained through generations 
to create order and stability in the face of uncertainty as family members engage in the entrepreneurial process.

\section{Literature analysis}

\section{Family entrepreneurship and entrepreneurial opportunities}

Family entrepreneurship is dependent upon entrepreneurship, family, and the family business (Randerson et al. 2015a). Central to family entrepreneurship is the core concept of entrepreneurial opportunity (McMullen 2007; Randerson et al. 2015b). It has been argued that opportunities emerge as an outcome of a process, and are in constant development by entrepreneurs. This is a view of entrepreneurial opportunities as a socially constructed process, influenced by the way entrepreneurs make sense of the information around them (Fletcher 2007; Korsgaard 2011), where various factors interact and are constantly modelled by the entrepreneur (Randerson et al. 2015b). Entrepreneurship is characterised as complex, with high levels of uncertainty and unfamiliarity, and the way opportunities are conceptualised is a key influence in the entrepreneurial process (Roscoe, Discua Cruz, and Howorth 2013; Randerson et al. 2015b).

The importance of family for family entrepreneurship is unequivocal (Randerson et al. 2016). Randerson, Dossena, and Fayolle $(2016,37)$ highlight that while families can take a variety of forms, family remains a 'mainframe' in which entrepreneurial knowledge can be fostered and entrepreneurial dispositions nurtured. The family plays a pivotal role in both the structural (e.g. births, marriages, deaths, conflict, and succession) and transactional dimensions, i.e. the way a business influences an individual mindset about entrepreneurship (Frank et al. 2010). While the structural view focuses on a traditional portrayal, binding a family group around legal or normative aspects, the transactional view asks researchers to consider family as 'a group of intimates who generated a sense of home and group identity and who experience a shared history and a shared future' (Koerner and Fitzpatrick 2002, 71). 
Instead, the transactional view of family highlights that the boundaries of family are socially constructed, suggesting variations in terms of culture, generation, and ideology about who can be considered as belonging to the family (Randerson et al. 2016). Every family, influenced by diverse dynamics, commitment, loyalty, and structure, provides a specific environment for the perception of enterprise, influencing the way family members act entrepreneurially (Frank et al. 2010).

Different studies highlight the concepts of entrepreneurial families, enterprising families, entrepreneurial households, families in business or business families (Hamilton et al. 2017; Nordqvist and Melin 2011; Frank et al. 2019). A common denominator in these conceptualisations is the existence of a social unit, composed of different members of a family over time who behave entrepreneurially, that is, they engage in family entrepreneurship. A family social network is informed by history and shared experiences. This network influences the entrepreneurial behaviour of its members and how entrepreneurial opportunities unfold (Randerson et al. 2016, 39). In family firms, entrepreneurial opportunities and their construction are dependent on family members performing activities together, engaging in shared labour and conversations about what needs to be done, what is involved, and why (Roscoe et al. 2013). To increase knowledge on how entrepreneurial opportunities are socially constructed, scholars call for further examination of the conversations that tie entrepreneurial families together (Konopaski, Jack, and Hamilton 2015), and the processes that allow a shared view of entrepreneurial opportunities (Randerson et al. 2015b) that can influence family entrepreneurship.

Understanding the way families construct entrepreneurial opportunities over time and across generations would advance knowledge of family entrepreneurship (Bettinelli, Fayolle, and Randerson 2014). Scholars acknowledge the role of family in developing several businesses over time using different combinations of family members with a shared understanding of the 
way to create an opportunity, but also stressing the heterogeneity of families and their approach to entrepreneurship (Discua Cruz, Howorth, and Hamilton 2013; Rosa, Howorth, and Discua Cruz 2014).

\section{Family as a social system}

Recent studies suggest that grasping how the entrepreneurial dynamics of families are shaped requires novel perspectives (Frank et al. 2010; von Schlippe and Frank 2013; Hasenzagl, Hatak and Frank 2018). Frank et al. (2010) adopt social systems theory (Luhmann 1995) to explain the complex relationship between family and enterprise over time. A social system is defined as an autopoietic (self-reproductive or referential), operatively closed system (all processes, such as internal rationality or schemas, are produced by the system itself) constituted through communication. A social system recursively reproduces itself through communication, which involves selecting what is being communicated (information) and why (understanding). One communication connects to another in a pattern, so the dynamic form of stability that we encounter in everyday communication emerges (von Schlippe and Frank 2013, 389). A communication is never linked to a single event/thing but situated in the context of preceding and subsequent communications. Thus, the act of communicating becomes an interactive and co-created process, constructing common meanings and experiences. Therefore, communication cannot be attributed to any one individual, but constitutes an emergent property of the interaction between many individuals.

The key paradigmatic shift offered by this perspective emphasises moving away from individuals as the elements of a social system to focus on the different communication logic of different fields of meaning. The theoretical advantage for research as well as practice is that it might be easier to describe the 'rules of the game' than understanding individual family members (von Schlippe and Frank 2013, 389). 
Von Schlippe and Frank (2013) explain that the kind of meaning generated to deal with complexity depends on the context in which it arises. Context determines how communication is to be framed, and the logic varies in function. In families, functional logic relates to the creation of connections for the continuation of communication. The family as a social system is orientated towards relationships, using communication mainly so that its members can confirm mutual attachment. Thus, von Schlippe and Frank (2013) argue that family as a social system consists of relational communication. Conceptualisation of an entrepreneurial family as a world of meaning-processing social systems requires research focused on understanding such communication.

\section{Family entrepreneurship, narratives, and metaphors}

Narrative is widely acknowledged as a source of knowledge for scholars engaged in theory building in entrepreneurship (Larty and Hamilton 2011; Hamilton 2014). Larty and Hamilton (2011) highlight the breadth of theories and methods applied in narrative research in entrepreneurship, calling for further development of literary approaches to theory building. Narrative research has illuminated the subtleties and complexities of entrepreneurial opportunities across generations (Hamilton 2006, 2013), challenging rationalist theoretical perspectives of opportunity discovery, evaluation, and exploitation. In contrast, it has highlighted entrepreneurial opportunity as emerging from social practice (Steyaert 2007).

A key element of narratives is found in metaphors (Semino and Demjén 2016). Metaphors are a form of linguistic device, where one thing is represented in terms of another. Metaphor has a powerful role in the development of entrepreneurship theory. Clarke et al. $(2014,250)$ theorise the entrepreneurial growth processes through an examination of metaphor, calling for research to clarify the 'meaning and application of particular metaphors'. In the context of family entrepreneurship, Hamilton $(2013,71)$ argues that particular metaphors are used in family members' narratives to express the hard work experienced whilst constructing 
entrepreneurial opportunities. The physicality of the language emphasises challenges or struggles faced during participation in the business. Narratives serve to capture how entrepreneurial families survive over time, both emotionally and physically.

Metaphors can constitute vivid and precise images of entrepreneurial experiences. Metaphors express complex or abstract ideas, or induce audiences to experience a particular relationship among apparently unrelated ideas - to make the unfamiliar familiar. Family stories make sense of unfamiliar concepts over time (Fiese and Pratt 2004). Metaphors facilitate the creation of situated meanings and group identity (Gberardi 2000), as they acquire and create meaning in the interactions of those who produce and uphold them. Thus, meaning resides in the situation in which the metaphor is used, in the community that uses it, and in the context of the action it generated. Moreover, a focus on metaphors of entrepreneurial opportunity, and how they might have implications for family members in the future (Semino and Demjén 2016), opens up avenues for theorising intergenerational family entrepreneurship.

\section{Transgenerational entrepreneurship and entrepreneurial legacy}

Transgenerational entrepreneurship focuses on how entrepreneurial opportunities are created by the incumbent family generation and those who succeed them (Nordqvist and Zellweger 2010). To explain how families nurture transgenerational entrepreneurship, Jaskiewicz, Combs, and Rau $(2015,31)$ put forward an entrepreneurial legacy theoretical perspective, defined as 'rhetorically reconstructed narratives of the family's past entrepreneurial behaviour or resilience - that motivate and give meaning to entrepreneurship'. It is argued that early involvement (from childhood) of family members imprints the family's entrepreneurial legacy through narratives that will motivate and give meaning to their future entrepreneurial behaviour (Jaskiewicz et al. 2015, 41). Jaskiewicz et al. (2015) call for further understanding the processes through which entrepreneurial families nurture entrepreneurship across generations. In the intersection between family and enterprise in family entrepreneurship (Randerson et al. 2015a), 
little is known about family narratives and how they may influence the interpretation of entrepreneurial opportunities, potentially leading to the creation of several businesses (Hamilton et al. 2017; Barbera, Stamm, and DeWitt 2018).

Konopaski et al. (2015) in their study of continuity of family firms suggest that family members learn in the context of reflections on past events and stories, which impact the way businesses are run and how new entrepreneurial opportunities are approached in the future. Continuity in family entrepreneurship across generations is deeply intertwined with entrepreneurial opportunities (Howorth, Jackson, and Discua Cruz 2014). Knowledge of opportunities can be embedded in entrepreneurial narratives (Hamilton 2013). Hammond, Pearson, and Holt $(2016,1210)$ suggest that family legacy represents 'a collective or shared perception reflecting a unique and continuous stream of meanings associated with the family that are transferred to and shared most often, but not always exclusively, among generations of family members through a collection of legacy artefacts. They further suggest that forms of verbal communication can influence sense-making, and as a consequence, members of the same family are likely to share similar frameworks and patterns of understanding. One of the legacy artefacts alluded to by Hammond et al. (2016) is shared family stories, yet little is known about what may be included in such stories and how they are communicated.

\section{Research Context and Methodology}

\section{Latin America and Honduras}

Randerson et al. (2015a) advocate exploring diverse contexts in family entrepreneurship research. Many theoretical frameworks and models developed in family business and entrepreneurship rely on an Anglo-American worldview. Instead, the present study focuses on Honduras, a developing Latin American country (World Bank 2018). Gupta et al. (2008) observe that family and business issues appear to be inseparable in the Latin American culture, with family participation in business being the norm. 
Honduras is characterised by a networked society in which mutual support and common action by family members are commonplace in business. Rarely is a business in Honduras not created or influenced by a family or kinship-related group (Discua Cruz et al. 2016). Honduras is typical of the Latin American context in terms of family influence in business activities and culture in business (Gupta et al. 2008). Family ties are a vital part of business dynamics, and family business dominates the economy (Roscoe et al. 2013).

\section{Methodology}

Our aim is to explore how metaphors provide a medium for shared understanding of opportunities, and how this influences family entrepreneurship. Since this study seeks to explore a phenomenon over time, we rely on qualitative longitudinal research design and the use of observation, conversations, and in-depth interviews to make sense of the situations of participants (Reay \& Zhang 2014; Barbera et al. 2018). As such, an interpretivist perspective and a focus on entrepreneurial narratives are used to theorise about family entrepreneurship (Larty and Hamilton 2011).

We purposefully selected entrepreneurial families that created several entrepreneurial opportunities over time, namely, cases with varying permutations of family involvement and with businesses in diverse sectors. While the purposive sampling method has received criticisms around distortion and insufficient breadth (Patton 1990), selecting cases using these criteria allow rich data to emerge based on the narratives of entrepreneurial families (Hamilton et al. 2017).

Four entrepreneurial families (Table 1) that had shaped a business portfolio over time were selected from a group of twelve that were part of a larger study on entrepreneurial dynamics. Privileged access to business networks in Honduras through the first author's family in business allowed open and rich interviews. The lead author who is familiar with the place and context identified participants relevant to our research interest and sampling approach, and conducted 
the interviews. Strong levels of trust between the interviewer and the families allowed extensive and open interviews over time. The lead author is theoretically sensitised with the knowledge and skills required for qualitative work (Glaser and Strauss 1967), and could thus remain neutral and non-judgemental in the interviewing process. Following Konopaski et al. (2015) and McKeever, Jack, and Anderson (2015), the other members of the research team were involved and engaged throughout the research process, constantly on hand to discuss the data, the emerging patterns and themes.

Data collection involved several in-depth interviews in the locations preferred by interviewees (e.g. business premises, vehicles, farm fields, homes), lasting between 1 and 2.5 hours with multiple respondents engaged in the creation of entrepreneurial opportunities. Interviews were recorded verbatim in Spanish (the first language of the interviewees and lead author). Initial interviews took place in 2006 with follow up interviews held in 2007, 2009, 2014, and 2016. A longitudinal approach was used to understand the rationale behind the entrepreneurial processes (Table 1). Subsequent interviews provided insights into the narratives and helped triangulate data. We revisited the perspectives, inviting participants to clarify meanings around the phenomena (Stake 2008). This approach allowed addressing potential issues of retrospective accounts (Loftus and Hoffman 1989), adding rigour to the methodology.

Interviews started with a general request: Tell me about yourself and the story behind this business. This elicited the recollection of vivid and often emotional life stories. Subsequent questions focused on the way businesses emerged, allowing participants to tell a story behind every venture created or acquired. This approach is considered emergent yet promising in understanding entrepreneurial families (Reay and Zhang 2014). The interview schedule (Appendix A) did not directly ask participants to think metaphorically, but to naturally express the language they use when creating entrepreneurial opportunities. The result was the discovery 
that metaphorical language pervaded the discourse of family entrepreneurship. Employing a metaphor to frame some aspect of a story allowed participants to narrate family entrepreneurship across time. When metaphors were expressed directly, they were often signalled with some lexical cue, such as 'is like' (e.g. creating a new firm is ...) (Steen et al. 2010).

\section{Data analysis}

In line with Dodd (2002, 524), the analytical approach proceeded as follows. First, all metaphors were extracted from the narrative material collected. This involved several careful word-by-word readings of the text, with metaphors placed in a separate file. A metaphor was determined under the following conditions (Schmitt 2005, 371): A word or phrase that can be understood beyond its literal meaning in the context of what is being said. The literal meaning stems from an area of physical or cultural experience (the source area) that is transferred to a second, often abstract, target area. Second, we reviewed the collection of metaphors and made notes of the vehicle and object of each metaphor (e.g. vehicle: 'connecting dots'; object/grounds: seeing a bigger picture) as shown in Table 2. This step involved evaluating the general meaning of the metaphor. Results were then collated both by vehicle and by object in tabular form directly from these annotations. Finally, a broader noun or concept was entered for each vehicle and object listed. This process resulted in the discovery of metaphors chosen to describe entrepreneurial opportunities. We adopted matrices to organise the data, collecting in-situ observation, field notes, margin notes, summaries, vignettes, diagrams, and mindmaps to support the data analysis (Miles, Huberman, and Saldana 2013), allowing us to understand the narratives of family entrepreneurship over time.

The analysis was iterative in that ideas emerging from the narrative data were compared with the literature using the constant comparative method to review data with emerging categories (Konopaski et al. 2015; McKeever et al. 2015). Guided by Konopaski et al. (2015), 
we moved from empirical data to description, thematic categorisation and interpretation, and finally, theoretical implications. This resulted in 'meaningful metaphors' used by members of the entrepreneurial families emerging from the iterative analysis of narratives (Oswick, Keenoy, and Grant 2002), arising as naturally as possible, rather than researcher-imposed (Dodd 2002).

Our methodology acknowledges that metaphors are 'culturally formed and located' (Dodd et al. 2013, 76). Interpretation thus requires knowledge of the background and context (Coulson and Oakley 2005), the language used (Dobrzyńska 1995), and translation (Parker et al. 2013). Whilst translation carries risks, particularly for metaphors, such issue is often not problematized (Temple and Young 2004). Our concern was to retain the metaphorical expressions of interviewees in their original language, and to avoid misunderstandings and over-interpretation. Thus, excerpts from the narrative interviews were translated only after the initial data analysis.

The cases selected are second and third generation family firms, representing the Honduran business landscape (Discua Cruz et al. 2016). In all cases, family members owned $100 \%$ of the equity, and nonfamily members did not have an ownership stake in any of the opportunities created. To preserve confidentiality, and at the participants' request, each case was given a fictitious name based on the founding business. The case vignettes of the four cases are as follows (also see Table 1).

The farmers family business started 100 years ago in the agriculture sector. Antonio, founder of the farmers estate, acquired vast amounts of land in Honduras in the 1900s. The business passed to Enrique Sr., who diversified into mass consumption crops, agricultural machinery rental, real estate, and livestock. The junior generation, educated in marketing and agronomy, created new firms related to non-traditional agriculture for export, grain mills, 
vegetable oil extraction, and agro-tourism. In 2000, Enrique Sr. retired to follow a political career.

The distributors family business started with Miles and Sonia opening a beverage distribution venture. Additional businesses in commuter transportation, coffee exports, ceramic manufacturing, xerography, processed food distribution, and advertising were gradually developed. Sonia died in the 1990s and several of the businesses had to cease operating. The junior generation pursued university degrees in law, business administration, and medicine. Junior generation members then engaged in the existing businesses and in the re-birth of Sonia's businesses. Miles retired in 2014.

The landowners family business started in the 1970s with Fernando and Maria acquiring the management rights of a small petrol station. They later diversified into fuel transportation, automotive replacement parts, and real estate. The junior generation diversified further, as all members had different ambitions and education, creating businesses in agriculture, construction, equipment transportation, and appliance distribution. In 2016, the senior generation retired due to health issues.

The transporters family started in the sector in the 1960s. Alberto and Laura gradually expanded their business through competitor acquisitions. The junior generation studied business management, agricultural engineering, and accountancy. Alberto Sr. died suddenly in 2007, a few months before this study began. Laura retired following Alberto's death. The junior generation were already managing existing businesses and developed additional ventures in cattle farming, construction, fast-food franchising, and specialised transportation.

[Insert Table 1 about here]

\section{Findings}

In this section, informed by Salvato and Aldrich (2012), Reay and Zhang (2014), and Frank and Landström (2016), we present the evidence from our findings of narratives of 
entrepreneurial opportunities in family entrepreneurship. Following Konopaski et al. (2015) we use 'power quotes' from the data to illustrate how family members communicate the concept of opportunity. The richness of repeated entrepreneurial experiences relied on metaphors to capture and explain the creation of opportunities. Findings highlight that metaphors assist the transfer of meanings from one generation to the next, provide a shared point of reference, create a connection between something familiar and something new, and link past, current, and future interactions. Table 2 presents the details of metaphors used to give meaning to entrepreneurial opportunities.

\section{[Insert Table 2 about here]}

\section{Metaphorical foundations: Early interaction in family and business}

The use of metaphorical language by entrepreneurial families was commonplace in the explanation of entrepreneurial opportunities. As Table 2 shows, the metaphors represent the underlying foundation of the entrepreneurial stories that are told and shared in the context of family businesses. Metaphors embody the environment where interaction between family members occurs, and where entrepreneurial family stories have meaning. In every narrative illustration, members of entrepreneurial families were able to convey their experience and knowledge of the entrepreneurial process, relying on knowledge of the conceptual and lexical domains in their business context (e.g. farming, transportation, logistics, real estate), supported by well-known concepts in the physical world (e.g. a journey, a game, a drawing).

The most representative power quote comes from transporters who illustrated a metaphor of entrepreneurial opportunities as 'being on the road, a journey'. Pedro stated:

...it was not until we 'were on the road', as Dad said, that we understood what business is

like... as children my brothers and I loved cars and trucks, and hey, our Dad had buses, so it was fun... Dad made sure we went with him on trips during vacation times or the 
weekends.... at the end of the day, we talked about what we saw on the trip, from the start to the end of the journey, the good, the bad, what was needed, the hidden costs, the joys and even about what new roadside businesses we could start along that route.

Alberto Jr. suggested young family members had to experience what 'being on the road' meant. A bus, a route, co-pilots, detours, hills, stop-signs, movement of people, shaped a shared view of interpreting entrepreneurial opportunities as a journey. Similar accounts were found in all cases, where metaphors are used not only to define and describe an experience, but also to serve as a template or reference, relying on familiar physical objects or experiences as vehicles, rendering abstract concepts (e.g. creating entrepreneurial opportunities) concrete and familiar.

Farmers articulated entrepreneurial opportunities around a metaphor linked to 'sowing and harvesting'. The language of opportunities refers to a field ready to be cultivated, preparing the soil, planting a new crop, a tree, and the natural elements involved. Enduring natural cycles that several generations encountered shaped the metaphorical approach, turning experiences into a shared collective memory of how to interpret entrepreneurial opportunities.

Distributors relied on 'connecting dots' and childhood memories of dot-to-dot drawings, arguing that family members can visualise entrepreneurial opportunities as connections. Resources needed to create an opportunity are described in terms of dots, lines are used to describe the way products would be distributed, and colours are associated with the weight of connection between dots.

Landowners described entrepreneurial opportunities in terms of playing a property-based game (Monopoly). They defined legal or commercial challenges in terms of game rules and gameplay, in tune with the real estate properties the family acquired over time. A board game is used not only as a family pastime but also as a way to introduce a familiar language of entrepreneurship to subsequent generations. 
Narrative illustrations suggest that the foundations of a metaphorical approach to entrepreneurial opportunities may be strongly dependent on the early interaction of family members, relying on a common language and vocabulary in a context that is safe, familiar, and linked to existing businesses and family spheres. Such metaphors represent collective memories shaped by positive interactions in the family and business context. Interpreting entrepreneurial opportunities through metaphors serves as an intergenerational educational device. Such shared experiences (e.g. dot-to-dot drawings, riding a bus, planting crops, playing games) create the metaphor's backstory, carrying meaning for the entrepreneurial family. Table 3 shows that the founder generation lays down a memory, perhaps unintentionally, yet highly developmental for the next generation, using a metaphorical approach to later make sense of entrepreneurial opportunities collectively.

[Insert Table 3 about here]

\section{Metaphorical association: Interconnections over time}

Metaphors are used not only to express meaning, but also influence how meaning of entrepreneurship as a process is constructed. Table 3 shows that a metaphorical approach allows transferring the meaning from one theme to another, acting as a vehicle to interpret several opportunities over time. Metaphors become a blueprint over time, a durable point of reference in the creation of several opportunities and the interpretation of entrepreneurship as a collective process.

A representative power quote comes from distributors, who highlighted that a 'connecting dots' metaphor provides a template when recreating entrepreneurial opportunities disrupted after the death of a family member. Antonio explained:

Ok, let me show you [draws several dots in a piece of paper, different colours]... imagine you want to create a food distribution of corn-based products... first we need to know what 
we have here [in existing businesses, resources, support] and what we can get our hands on before we start, I could see some dots, and my brother can tell of you of others ...each dot we think of will have a different weight or characteristic... then we stand back and gradually start making the connections, one of us can start from who we know, the other from what we have, and so on.... what we experienced together from those dots is what allows us to connect them ... At the end you have a picture that makes sense to all of us...

For distributors, creating entrepreneurial opportunities as 'connecting dots' entails comparing the nature of a dot-to-dot drawing and its relation to people, products, customers, or existing commercial and personal networks over time. Metaphors allow constant connections between formal and informal 'rules of the game', such as government regulations or property investments, and the chances, risks, and rewards of engaging in the entrepreneurial process.

For landowners, the game metaphor allows interpreting opportunities around real estate development as a monopoly game, implying a process where more than one business venture can emerge. This occurred as the senior generation acquired several real estate properties, and the junior generation was encouraged to think metaphorically about the investment and related businesses whilst playing the game. Complex concepts such as chance and luck in business, which may determine the progress (or regression) of an individual player toward the attainment of his/her goal in a game, are explained by metaphorical associations. Playing a game relates to creating entrepreneurial opportunities that sharpen business judgment, as family members have to master the rules of the game, manage resources, and plan accordingly.

The narrative illustrations highlight that whilst comparison between domains of knowledge is simplified when opportunities are created over time in areas related to existing businesses (e.g. agricultural-based ventures in farmers), associations between seemingly disconnected areas are also made through metaphors. 
Transporters relied on 'being on the road' when a new unrelated business in fast-food restaurants was started. Ambiguity and adaptation in a new industry for all entrepreneurial families also led to drawing on the metaphorical approach. Uncertainty is associated with 'bumps' or 'road maintenance works' that may slow down the process, or 'roadblocks' that may change the route or ending up in unexpected places. Family members referred to the metaphor as they illustrated how they advanced from the starting point of the journey (e.g. fastfood restaurant idea) to a destination (e.g. start of trading), relating the process to transportation terms they had become familiar with over the years. The journey demanded diverse skills and information from others as well as resources when 'driving' in uncharted territory. The comparisons made through 'being on the road' encouraged a collective approach to anticipate unexpected 'twists' and 'turns' in the entrepreneurial process.

Metaphors allow family members to frame information (e.g. changes in customer demand, industry, etc.) and create a common reference point about what an entrepreneurial opportunity looks like in both familiar and unfamiliar business sectors, allowing wider connections over time to be made (e.g. who to contact first, which resources to use and when). Table 3 shows that metaphors represent accounts of what an entrepreneurial opportunity is, difficult to articulate otherwise, becoming part of a socially constructed meaning for entrepreneurial families.

\section{Continuity of a metaphorical approach: Reinforcing social structures and belonging}

The narrative illustrations reveal that a metaphorical approach is reinforced by, and in turn reinforces, the social structures of an entrepreneurial family over time and across generations. Whilst beneficial to creating a durable and shared point of reference, this also entails unintended exclusionary features. A power quote by Gerardo from transporters highlights this notion: 
...well, thinking like that [based on being on the road] when looking at new businesses works for us because we witnessed what my Dad meant, we heard it at the dinner table, when we were "on the road". He discussed it only with us - his family. He would not talk about it with anyone else. I still remember the smell of grease in the bus repair shop when we returned from a long trip over the weekend and the way he would talk about getting to a new destination and how he solved the problems on the road as they appeared... we all remember that... we met the other day with my mom and recalled each of our anecdotes. I mean, we can all talk about being on a journey with him and what he explained, it was the way he explained, the examples he used that we still remember and apply because they work for us.

For transporters, 'being on the road' was cemented as the family point of reference after their father's death, reinforcing a shared identity as an entrepreneurial family.

The narrative illustrations highlight that family gatherings and other social contexts both at home and at the business reinforce a shared way of creating opportunities. The notions of exclusion highlighted in Table 3 suggest that whilst the well-accepted metaphors of entrepreneurial opportunity may appear straightforward, it is the interpretation and experiences behind the meaning of such metaphors that create a unique shared reference point for family entrepreneurship. Table 3 also shows that the role of family members in ensuring continuity of meanings associated with a metaphorical approach carries an emotional weight. Such relationships help 'establish in-group language and identity', whereby shared understanding of metaphors becomes a vehicle for the inclusion or exclusion of others (Cameron 2003, 24). Members of the same entrepreneurial family may use similar metaphors to explain their experiences and interpretations of entrepreneurial opportunities.

Table 3 further reveals that metaphors embody a 'gate-keeping role', regulating participation in family entrepreneurship activities. The narrative illustrations show members 
strongly associate their metaphorical approach with their shared experiences, and thus the meaning and interpretation of the metaphor for entrepreneurship would automatically exclude those who lack such experiences. Metaphors ensure the continuity of the socio-cultural dynamics of the family and shared understanding of entrepreneurial opportunities. The use of metaphors assists entrepreneurial families over time to make sense of their world and their place in it, and so assisting in the creation of a social reality for the members of the entrepreneurial family.

\section{Discussion}

Our findings indicate the significance of metaphors for theorising family entrepreneurship, especially in line with social systems theory, entrepreneurial legacy, and the social construction of opportunity.

\section{Metaphors and social systems theory}

This study shows how metaphors allow the entrepreneurial family to make sense of the complexity of the surrounding environment (von Schlippe and Frank 2013; Oswick et al. 2002; Lakoff and Johnson 1980), and that entrepreneurial family stories and metaphors specifically can create boundaries.

Metaphors provide meaning to entrepreneurial families, and meaning delimits a social system from its environment. As such, it creates a system-environment boundary. These meanings, created via communication (Frank et al. 2019), incorporate three dimensions: a factual one (e.g. creation of a new venture), a social one (e.g. creating a trans-generational cohesion), and a temporal dimension (e.g. providing information on how to develop an opportunity in terms of 'before-after'). Family business heterogeneity is important, as each may uniquely differ from another family business (Dibrell and Memili 2019), and these heterogeneous attributes can take many forms. However, identities of social systems, such as 
family business, are based on self-description and constructed through narrative (Frank et al. 2019). This reflective self-conception (Frank et al. 2019) can reinforce identity and guide behaviour. Our findings show that no one else can share the entrepreneurial family stories, because they are kept within the family. Only the family who experience the activities behind the metaphor are within the boundary, and therefore, the stories frame the boundary of the family business. Animating metaphors through shared experiences provides new understanding of what can tie members of a social group (Cameron 2003).

\section{Entrepreneurial Opportunities}

In terms of entrepreneurial opportunities and family entrepreneurship, this study contributes to the view that entrepreneurial opportunities are socially constructed through language and shared entrepreneurial family stories. Metaphors facilitate the construction of entrepreneurial opportunities by providing a bridge 'from the familiar to the strange' (Cornelissen 2005; Clarke et al. 2014). While the transactional view deems that opportunities are socially constructed, it says much less about how this occurs. Our findings show that opportunities are constructed through entrepreneurial family stories that develop shared understanding of opportunity recognition, evaluation, and exploitation. Language is an important part of this construction of opportunities in family entrepreneurship. There are other stories within families, but entrepreneurial family stories are about how these families engage in entrepreneurship.

Creating entrepreneurial opportunities is a process filled with unexpected turns and new experiences, and the entrepreneurial family, as a social unit, responds by making sense of the process through its own internal schema. What we see in this study is that metaphors can act as basic yet powerful shared constructs for organising knowledge of the world by relating phenomena (e.g. entrepreneurial opportunities) to something previously experienced and concrete. In so doing, metaphors transfer 'familiness' (Frank et al. 2010) to entrepreneurial opportunities. In the process of making decisions, metaphors can allow an entrepreneurial 
family, as a social system, to construct future-oriented representations of entrepreneurial opportunities (Hill and Levenhagen 1995). The context that the family acts on is constructed through interaction with metaphors (Gaddefors 2007). Such interaction may facilitate an entrepreneurial family, as a social system, to act upon opportunities over time.

The narrative illustrations reveal that entrepreneurial families perceive how entrepreneurial opportunities 'come to be' rather than 'exist'. Entrepreneurial opportunities are contingent on family members in business communicating over time, existing in specific temporal and geographic contexts, and in relation to others (Roscoe et al. 2013). As evidenced by the narrative illustrations, metaphors allow interpretation and action without hiding the complexity and uncertainty of the entrepreneurial process.

\section{Learning effect of metaphors in entrepreneurial legacy}

Key studies of legacy (e.g. Hammond et al. 2016; Jaskiewicz et al. 2015; Barbera et al. 2018) highlight the significance of family stories, but little has been said about the language of family entrepreneurship. This study shows that entrepreneurial family stories and metaphors specifically connect the family members through time, and so to legacy. Theorising entrepreneurial legacy points to the importance of entrepreneurial family stories. This paper contributes to understanding what those stories consist of, and how they carry shared meanings through transmission and translation, that is, how they are socially constructed. Particular social practices of family entrepreneurship are embedded in metaphors, and metaphors draw upon shared experiences specific to each entrepreneurial family. Metaphors emerge as the result of a relational process, and entrepreneurial opportunities are socially constructed between and across generations. Whilst metaphors appear to be commonplace, they are the outcome of interactions and a relational process that belong to the family's private realm. This occurs from an early age, thus influencing the development of family legacy, and implying that through metaphors, transgenerational family entrepreneurship may emerge (Hamilton et al. 2017). 
The narrative illustrations show that the purpose of metaphors is unveiled in the interaction between founding and subsequent generations. They offer a succinct method of instruction in practical ways. Metaphors invite family members to reflect on the world and their shared experiences, turning into a vehicle for entrepreneurial learning (Konopaski et al. 2015) that connects the family and enterprise realm in family entrepreneurship. While the connotations of some metaphors (e.g. journey, connecting dots) may be universal in scope (Dodd 2002), they reflect the lives of the families behind the businesses and the continuity of entrepreneurial engagement. This is not to say, we emphasise, that the metaphors discussed here are not applicable to other families. Families around the world have the same concerns about business continuity and how to go about engaging in further entrepreneurial activities (Rosa et al. 2014; Howorth et al. 2014). The study reported here shows that metaphors are used to communicate entrepreneurial insight, and relayed to those who may be successors in existing firms or leaders in independent businesses in the future. The learning effect of metaphors may also influence family members who decide to establish family businesses on their own over time (Discua Cruz et al. 2013). Metaphors as connected acts of communication and legacy artefacts allow family entrepreneurship to pass from one entrepreneurial family to other entrepreneurial families over time. Therefore, family metaphors deserve to be recognised for their impact on entrepreneurial behaviour and their potential to influence family entrepreneurship across generations.

\section{Limitations and further research}

This article has some limitations that provide opportunities for future research. First, we have examined a metaphor-based approach to family entrepreneurship at the micro level of analysis, that is, at the communication process micro level (e.g. interpersonal communication between family members). In terms of longitudinal research, such approach is challenging for reasons including cost, time, and cooperation between the researcher and the entrepreneurial family 
under study (Hassett and Paavilainen-Mäntymäki 2013). When conducting longitudinal research, many unpredictable events may occur that can affect the entire research process. In the course of this study, two families decided to sell most of their businesses and migrate overseas, while others stopped establishing new firms after the 2009 political coup in Honduras (Ruhl 2010). This poses a limitation for progressive approaches, particularly in uncertain and unstable contexts (Gupta et al. 2008). Future studies might focus on a narrative approach to study metaphors that have either survived or eroded in long established family firms in the same industry and country beyond the 5th or 6th generation (Nordqvist and Zellweger 2010), or in newly formed firms around the world (Zhang and Reay 2018). Further studies might also look at different levels of analysis, for example, a metaphorical approach to understand the ways family members communicate in the context of corporate entrepreneurship (Bettinelli et al. 2017). A wider view of family and its extensions is also of interest. For instance, for social systems theory, an underlying question might relate to who is part of the business family and who is not (see Frank et al. 2019).

Second, metaphors in this article are portrayed as largely unproblematic, but we acknowledge the ambiguity and elusiveness of metaphors (Inns 2002). Hence, we do not claim that these metaphors are universal, rather that they are part of the everyday language of entrepreneurial families and appear to influence the approach to family entrepreneurship. Nevertheless, narrative illustrations can shed light on our understanding of entrepreneurial families over time and help further decipher the language of family entrepreneurship. Important to note is that we do not suggest that metaphors presented in this article can be generalised to entrepreneurial families around the world, yet we believe that metaphors, as a way to interpret entrepreneurial opportunities, are transferable to engagement in family entrepreneurship in any setting. 
A further limitation is that metaphors may be solely linked to elements of the actual phenomenon where it can provide a better illustration of the process. Ritchie (2013) cautions that the underlying meanings of metaphors may be ambiguous, and may be interpreted differently by different people based on their own unique experiences. Such underlying meanings may also change over time, as familiar metaphors may be reinterpreted in light of new cultural experiences, or in the case of entrepreneurial families creating new businesses, or when succession is disrupted. The embodiment of metaphors is often influenced by cultural beliefs and practices, and it is thus important to consider culture in any account of metaphors used by entrepreneurial families. Randerson et al. (2016) highlight that the differences among families across cultures, legal systems, and religions merit attention.

To address these concerns, further studies would benefit from exploring items related to emotions, intentions, and cultural diversity in the study of metaphors. For instance, emotional features of metaphors remain largely unexplored in the context of entrepreneurial families (Shepherd 2016).

The use of narrative analysis, metaphors specifically, is fruitful and promising in theorising family entrepreneurship. Narratives are a way to look at phenomena in family entrepreneurship. We build on the work of Anderson, Drakopoulou Dodd, and Jack (2009), and Larty and Hamilton (2011) to provide a guiding framework for future methodological approaches. However, we also show that further reflections on the emotional features of metaphors are needed (Dodd 2002). Conflicts or issues within entrepreneurial families working together may hinder the appreciation of metaphors and affect the approach to entrepreneurial opportunities (Discua Cruz et al. 2013), and thus family entrepreneurship (Randerson et al. 2015a). Future studies could explore to what extent metaphors emerge 'deliberately' in the context of entrepreneurial families (Dodd 2002). 
Finally, in most entrepreneurship and metaphor studies, English is the lingua franca, yet we suspect metaphors are used by entrepreneurial families around the world. The underlying processes of metaphor are a basic human skill, but different languages construct metaphors differently. Every language has lexical resources to bring together two ideas. Different languages have a particular set of conventionalised metaphors, partly linked to culture and partly the result of historical accident. Primary conceptual metaphors occur in all languages, but the linguistic expressions are likely to differ. Future research could expand on how family members give meaning to their metaphorical expressions in diverse cultures and contexts through narratives and metaphors (Semino and Demjén 2016). Metaphors may provide clues to deeper layers of meaning and unusual cultural translations of entrepreneurial families. Some metaphors may be universal and thus common in language, not just in Spanish or English, but also in cultures around the world (Anderson et al. 2009).

Moreover, as well as the potential limitations of type of respondent and interview content, future interviews may be fruitfully conducted by groups of researchers (e.g. Johannisson et al. 2007). This may be appropriate in contexts where cultural and language similarities are found, particularly for qualitative work (Bechhofer, Elliott, and McCrone 1984).

\section{Conclusion}

In examining how metaphors provide a medium for shared understanding of opportunities, this study contributes to knowledge on family entrepreneurship as a social and discursive process where meanings and values are communicated and maintained in everyday interactions. In enhancing understanding of the processes through which entrepreneurial families nurture entrepreneurship across generations, it also contributes to theorising transgenerational family entrepreneurship (Randerson et al. 2015a). This study contributes to family entrepreneurship theory by demonstrating how metaphors of entrepreneurial opportunity are shared with and 'imprinted' on family members. Metaphors of entrepreneurial opportunity are a vehicle for 
conveying the unique and continuous stream of meanings identified by Hammond et al. (2016). This study demonstrates metaphors are a significant feature of entrepreneurial legacy.

Metaphors, as legacy artefacts, are important in the everyday language of family entrepreneurship. We have provided evidence that entrepreneurial legacy may become purposeful through narrative elements such as metaphors. Metaphors are developed, communicated, and then translated into forms of family entrepreneurial action.

Our study shows that the way entrepreneurial families communicate about entrepreneurial opportunities is replete with metaphors, and that the language of family entrepreneurship may appear simple, yet is a highly complex and coordinated exercise. Some metaphors are enduring and form part of the entrepreneurial legacy. A key contribution of this study is that analysing metaphors and patterns of metaphor use contribute both to our understanding of family entrepreneurship and the contexts in which metaphors are used. Metaphors are the symbolic language of a process, of change, of a metamorphosis, narrating processes of family entrepreneurship across generations.

The practical implications of this study suggest that through metaphors, as the outcome of connected communication, family members in business may be able to simplify approaches to entrepreneurial opportunities and make them familiar over generations. Metaphors can have the same effect as a full story because they already have stories associated with them that are embedded in the minds of the members of the entrepreneurial family. The main contribution of this article is therefore establishing the link between metaphor as a narrative element and family entrepreneurship and opening up new avenues for further studies in the field of family entrepreneurship.

\section{References}

Anderson, A. R. 2000. "Paradox in the Periphery: An Entrepreneurial Reconstruction?" Entrepreneurship \& Regional Development 12 (2): 91-109. doi.org/10.1080/089856200283027. 
Anderson, A. R., S. Drakopoulou Dodd, and S. L. Jack. 2009. "Aggressors; Winners; Victims and Outsiders: European Schools' Social Construction of the Entrepreneur." International Small Business Journal 27 (1): 126-136. doi.org/10.1177/0266242608098349.

Barbera, F., I. Stamm, and R-L DeWitt. 2018 "The Development of an Entrepreneurial Legacy: Exploring the Role of Anticipated Futures in Transgenerational Entrepreneurship." Family Business Review 31 (3): 352-378. doi.org/10.1177/0894486518780795.

Bechhofer, F., B. Elliott, and D. McCrone. 1984. "Safety in Numbers: On the Use of Multiple Interviewers." Sociology 18 (1): 97-100. doi.org/10.1177/0038038584018001009.

Bettinelli, C., A. Fayolle, and K. Randerson. 2014. "Family Entrepreneurship: A Developing Field." Foundations and Trends ${ }^{\circledR}$ in Entrepreneurship 10 (3): 161-236. doi.org/10.1561/0300000049.

Bettinelli, C., S. Sciascia, K. Randerson, and A. Fayolle. 2017. "Researching Entrepreneurship in Family Firms." Journal of Small Business Management 55 (4): 506-529. doi.org/10.1111/jsbm.12347.

Cameron, L. 2003. Metaphor in Educational Discourse. London: Bloomsbury Academic.

Clarke, J., R. Holt, and R. Blundel. 2014. "Re-Imagining the Growth Process: (Co)-Evolving Metaphorical Representations of Entrepreneurial Growth.” Entrepreneurship \& Regional Development 26 (3-4): 234-256. doi.org/10.1080/08985626.2014.888099.

Cornelissen, J. P. 2005. "Beyond Compare: Metaphor in Organization Theory." The Academy of Management Review 30 (4): 751-764. doi.org/10.2307/20159166.

Coulson, S., and T. Oakley. 2005. "Blending and Coded Meaning: Literal and Figurative Meaning in Cognitive Semantics." Journal of Pragmatics 37: 1510-1536. doi.org/10.1016/j.pragma.2004.09.010.

Dibrell, C., and E. Memili. 2019. "A brief history and a look to the future of family business heterogeneity: an introduction". In The Palgrave Handbook of Heterogeneity among Family Firms, edited by E. Memili and C. Dibrell, 1-15. Cham: Palgrave Macmillan.

Discua Cruz, A., C. Howorth, and E. Hamilton. 2013. "Intrafamily Entrepreneurship: The Formation and Membership of Family Entrepreneurial Teams." Entrepreneurship Theory and Practice 37 (1): 17-46. doi.org/10.1111/j.1540-6520.2012.00534.x.

Discua Cruz, A., C. R. Rodas, C. Raudales, and L. Fortin. 2016. "Large Family Businesses in Honduras: The Influence of State Intervention and Immigration in the Twentieth Century". In Evolution of Family Businesses: Continuity and Change in Latin America and Spain, edited by P. Fernández Pérez and A. Lluch. 196-215. Cheltenham: Edward Elgar.

Dobrzyńska, T. 1995. "Translating Metaphor: Problems of Meaning." Journal of Pragmatics, Literary Pragmatics: Cognitive Metaphor and the Structure of the Poetic Text, 24 (6): 595604. doi.org/10.1016/0378-2166(95)00022-K.

Dodd, S. 2002. "Metaphor and Meaning, a Grounded Cultural Model of US Entrepreneurship." Journal of Business Venturing 17: 519-535. doi.org/10.1016/S0883-9026(01)00072-6.

Dodd, S. D., S. L. Jack, and A. R. Anderson. 2013. "From Admiration to Abhorrence: The Contentious Appeal of Entrepreneurship across Europe." Entrepreneurship \& Regional Development 25 (1-2): 69-89. doi.org/10.1080/08985626.2012.746878.

Fiese, B. H. and M. W. Pratt. 2004. "Life Course and Systems Perspectives on Narrative". In Family Stories and the Life Course: Across Time and Generations. Edited by M. W. Pratt, and B. H. Fiese, 401-418. London (UK): Routledge.

Fletcher, D. 2007. "Toy Story': The Narrative World of Entrepreneurship and the Creation of Interpretive Communities." Journal of Business Venturing, 22 (5): 649-672. doi.org/10.1016/j.jbusvent.2006.10.001. 
Frank, H., and H. Landström. 2016. "What Makes Entrepreneurship Research Interesting? Reflections on Strategies to Overcome the Rigour-relevance Gap." Entrepreneurship \& Regional Development 28 (1-2): 51-75. doi.org/10.1080/08985626.2015.1100687.

Frank, H., M. Lueger, L. Nosé, and D. Suchy. 2010. "The Concept of 'Familiness': Literature Review and Systems Theory-Based Reflections.” Journal of Family Business Strategy 1 (3): 119-130. doi.org/10.1016/j.jfbs.2010.08.001.

Frank, H., J. Suess-Reyes, E. Fuetsch, and A. Kessler. 2019. "Introducing the Enterpriseness of Business Families: A research agenda". In The Palgrave Handbook of Heterogeneity among Family Firms, edited by E. Memili and C. Dibrell, 263-296. Cham: Palgrave Macmillan.

Gaddefors, J. 2007. "Metaphor Use in the Entrepreneurial Process." International Journal of Entrepreneurial Behaviour \& Research, 13 (3): 173-193. doi.org.ezproxy.lancs.ac.uk/10.1108/13552550710751049.

Gberardi, S. 2000. "Where Learning Is: Metaphors and Situated Learning in a Planning Group." Human Relations 53 (8): 1057-1080. doi.org/10.1177/0018726700538002.

Glaser, B. G., and A. L. Strauss. 1967. The Discovery of Grounded Theory: Strategies for Qualitative Research. Chicago: Aldine Press.

Gupta, V., N. Levenburg, L. Moore, J. Motwani, and T. Schwarz. 2008. Culturally Sensitive Models of Family Businesses in Latin America. A Compendium on the Family Business Models Around the World. Hyderabad: ICFAI University Press.

Hamilton, E. 2006. "Whose Story Is It Anyway? Narrative Accounts of the Role of Women in Founding and Establishing Family Businesses." International Small Business Journal 24 (3): 253-271. doi.org/10.1177/0266242606063432.

Hamilton, E. 2013. Entrepreneurship Across Generations: Narrative, Gender and Learning in Family Business. Cheltenham: Edward Elgar.

Hamilton, E. 2014. "Entrepreneurial Narrative Identity and Gender: A Double Epistemological Shift." Journal of Small Business Management 52 (4): 703-712. doi.org/10.1111/jsbm.12127.

Hamilton, E., A. Discua Cruz, and S. L. Jack. 2017. "Re-Framing the Status of Narrative in Family Business Research: Towards an Understanding of Families in Business." Journal of Family Business Strategy 8 (1): 3-12. doi.org/10.1016/j.jfbs.2016.11.001.

Hammond, N. L., A. W. Pearson, and D. T. Holt. 2016. "The Quagmire of Legacy in Family Firms: Definition and Implications of Family and Family Firm Legacy Orientations." Entrepreneurship Theory and Practice 40 (6): 1209-1231. doi.org/10.1111/etap.12241.

Hasenzagl, R., I. Hatak and H. Frank. 2018. "Problematizing socioemotional wealth in family firms: a systems-theoretical reframing". Entrepreneurship \& Regional Development, 30 (12), 199-223. doi.org/10.1080/08985626.2017.1401123.

Hassett, M. E, and E. Paavilainen-Mäntymäki. 2013. Handbook of Longitudinal Research Methods in Organisation and Business Studies. Cheltenham: Edward Elgar.

Hill, R. C., and M. Levenhagen. 1995. "Metaphors and Mental Models: Sensemaking and Sensegiving in Innovative and Entrepreneurial Activities." Journal of Management 21 (6): 1057-1074. doi.org/10.1177/014920639502100603.

Howorth, C., J. Jackson, and A. Discua Cruz. 2014. "Entrepreneurship in Family Businesses." In Handbook of Research in Small Business and Entrepreneurship, edited by E. Chell and M. Karatas-Ozkan, 333-357. Cheltenham: Edward Elgar. 
Inns, D. 2002. "Metaphor in the Literature of Organizational Analysis: A Preliminary Taxonomy and a Glimpse at a Humanities-Based Perspective." Organization 9 (2): 305330. doi.org/10.1177/1350508402009002908.

Jaskiewicz, P., J. G. Combs, and S. B. Rau. 2015. "Entrepreneurial Legacy: Toward a Theory of How Some Family Firms Nurture Transgenerational Entrepreneurship." Journal of Business Venturing, 30 (1): 29-49. doi.org/10.1016/j.jbusvent.2014.07.001.

Johannisson, B., L. Centeno Caffarena, A. F. Discua Cruz, M. Epure, E. Hormiga Pérez, M. Kapelko, K. Murdock, et al. 2007. "Interstanding the Industrial District: Contrasting Conceptual Images as a Road to Insight." Entrepreneurship \& Regional Development 19 (6): 527-554. doi.org/10.1080/08985620701671882.

Koerner, A. F., and M. A. Fitzpatrick. 2002. "Toward a Theory of Family Communication." Communication Theory 12 (1): 70-91. doi.org/10.1111/j.1468-2885.2002.tb00260.x.

Konopaski, M., S .L. Jack, and E. Hamilton. 2015. "How Family Business Members Learn About Continuity." Academy of Management Learning \& Education 14 (3): 347-364. doi.org/10.5465/amle.2014.0244.

Korsgaard, S. 2011. "Entrepreneurship as Translation: Understanding Entrepreneurial Opportunities through Actor-Network Theory." Entrepreneurship \& Regional Development 23 (7-8): 661-680. doi.org/10.1080/08985626.2010.546432.

Lakoff, G., and M. Johnson. 1980. "Conceptual Metaphor in Everyday Language.” The Journal of Philosophy 77 (8): 453-486. doi.org/10.2307/2025464.

Larty, J., and E. Hamilton. 2011. "Structural Approaches to Narrative Analysis in Entrepreneurship Research Exemplars from Two Researchers." International Small Business Journal 29 (3): 220-237. doi.org/10.1177/0266242611401796.

Loftus, E. F., and H. G. Hoffman. 1989. "Misinformation and Memory: The Creation of New Memories." Journal of Experimental Psychology: General 118 (1): 100-104. doi.org/10.1037/0096-3445.118.1.100.

Luhmann, N. 1995. Social Systems. Stanford, CA: Stanford University Press.

McKeever, E., S. Jack, and A. Anderson. 2015. "Embedded Entrepreneurship in the Creative Re-Construction of Place." Journal of Business Venturing, 30 (1): 50-65. doi.org/10.1016/j.jbusvent.2014.07.002.

McMullen, J. S. 2007. "What Is an Entrepreneurial Opportunity?" Small Business Economics 28 (4): 273-283. doi.org/10.1007/s11187-006-9040-z.

Miles, M. B., A. M. Huberman, and J. Saldana. 2013. Qualitative Data Analysis: A Methods Sourcebook. $3^{\text {rd }}$ edition. Thousand Oaks, California: SAGE.

Nordqvist, M., and L. Melin. 2011. "Entrepreneurial Families and Family Firms." Entrepreneurship \& Regional Development 22 (3-4): 211-39. doi.org/10.1080/08985621003726119.

Nordqvist, M., and T. Zellweger. 2010. Transgenerational Entrepreneurship : Exploring Growth and Performance in Family Firms across Generations. Cheltenham: Edward Elgar.

Oswick, C., T. Keenoy, and D. Grant. 2002. "Note: Metaphor and Analogical Reasoning in Organization Theory: Beyond Orthodoxy." Academy of Management Review 27 (2): 294303. doi.org/10.5465/AMR.2002.6588045.

Parker, M., R. Thomas, C. Steyaert, and M. Janssens. 2013. "Multilingual Scholarship and the Paradox of Translation and Language in Management and Organization Studies." Organization 20 (1): 131-142. doi.org/10.1177/1350508412460998. 
Patton, M.Q. 1990. Qualitative Evaluation and Research Methods. 2nd ed. Newbury Park, CA: Sage.

Randerson, K., C. Bettinelli, A. Fayolle, and A. R. Anderson. 2015a. "Family Entrepreneurship as a Field of Research: Exploring Its Contours and Contents." Journal of Family Business Strategy 6 (3): 143-154. doi.org/10.1016/j.jfbs.2015.08.002.

Randerson, K., J-M. Degeorge, and A. Fayolle. 2015b. "Entrepreneurial Opportunities: How Do Cognitive Styles and Logics of Action Fit In?" International Journal of Entrepreneurship and Small Business 27 (1): 19-39. doi.org/10.1504/IJESB.2016.073353.

Randerson, K., G. Dossena, and A. Fayolle. 2016. "The Futures of Family Business: Family Entrepreneurship.” Futures (75): 36-43. doi.org/10.1016/j.futures.2015.10.008.

Reay, T., and Z. Zhang. 2014. "Qualitative Methods in Family Business Research." In The SAGE Handbook of Family Business, edited by Melin, L., M. Nordqvist, and P. Sharma, 573-593. London: SAGE.

Ritchie, L. D. 2013. Metaphor. Key Topics in Semantics and Pragmatics. Cambridge: Cambridge University Press. doi.org/10.1017/CBO9781139136822.

Rosa, P., C. Howorth, and A. Discua Cruz. 2014. "Habitual and Portfolio Entrepreneurship and the Family in Business." In The SAGE Handbook of Family Business, edited by Melin, L., M. Nordqvist, and P. Sharma, 364-382. London: SAGE.

Roscoe, P., A. Discua Cruz, and C. Howorth. 2013. "How Does an Old Firm Learn New Tricks? A Material Account of Entrepreneurial Opportunity.” Business History 55 (1): 5372. doi.org/10.1080/00076791.2012.687540.

Ruhl, J. M. 2010. "Honduras Unravels." Journal of Democracy 21 (2): 93-107. doi:10.1353/jod.0.0170.

Salvato, C., and H. E. Aldrich. 2012. “'That's Interesting!' In Family Business Research.” Family Business Review 25 (2): 125-135. doi.org/10.1177/0894486512446327.

Schmitt, R. 2005. "Systematic Metaphor Analysis as a Method of Qualitative Research." The Qualitative Report 10 (2): 358-394. https://nsuworks.nova.edu/tqr/vol10/iss2/10.

Semino, E., and Z. Demjén. 2016. The Routledge Handbook of Metaphor and Language. New York: Routledge.

Shepherd, D. A. 2016. "An Emotions Perspective for Advancing the Fields of Family Business and Entrepreneurship Stocks, Flows, Reactions, and Responses." Family Business Review 29 (2): 151-158. doi.org/10.1177/0894486516634943.

Stake, R. E. 2008. “Qualitative Case Studies.” In Strategies of Qualitative Inquiry, edited by Lincoln, N. and Y. Denzin, 3rd edition, 119-150. London: SAGE.

Steen, G. J., A. G. Dorst, J. B. Herrmann, A. A. Kaal, and T. Krennmayr. 2010. "Metaphor in Usage." Cognitive Linguistics 21 (4): 765-796. doi.org/10.1515/cog1.2010.024.

Steyaert, C. 2007. "Entrepreneuring as a Conceptual Attractor? A Review of Process Theories in 20 Years of Entrepreneurship Studies." Entrepreneurship \& Regional Development 19 (6): 453-477. doi.org/10.1080/08985620701671759.

Temple, B., and A. Young. 2004. "Qualitative Research and Translation Dilemmas." Qualitative Research 4 (2): 161-178. doi.org/10.1177/1468794104044430.

Von Schlippe, A., and H. Frank. 2013. "The Theory of Social Systems as a Framework for Understanding Family Businesses." Family Relations 62 (3): 384-398. doi.org/10.1111/fare.12010.

World Bank. 2018. "Doing Business in Honduras - World Bank Group." http://www.doingbusiness.org/data/exploreeconomies/honduras (accessed April 20, 2018) 
Zhang, Z., and T. Reay. 2018. "Managing the Yin and Yang of Family Capital: A Study of Chinese Immigrant Entrepreneurs." Entrepreneurship \& Regional Development 30 (78): 722-748. doi.org/10.1080/08985626.2018.1457085. 
Table 1. Descriptive information of entrepreneurial families interviewed

\begin{tabular}{|c|c|c|c|c|c|c|c|c|c|c|}
\hline Family & Business portfolio & $\begin{array}{l}\text { Size (total } \\
\text { number of } \\
\text { employees) } \\
\text { April } 2017\end{array}$ & $\begin{array}{l}\text { First } \\
\text { business } \\
\text { founded }\end{array}$ & $\begin{array}{l}\text { Number of } \\
\text { businesses } \\
\text { currently in } \\
\text { the } \\
\text { portfolio }\end{array}$ & $\begin{array}{l}\text { Latest } \\
\text { business } \\
\text { founded }\end{array}$ & $\begin{array}{l}\text { Family } \\
\text { members } \\
\text { interviewed }\end{array}$ & Generation & $\begin{array}{l}\text { Number of } \\
\text { core } \\
\text { interviews } \\
2006^{\mathbf{a}} \\
\mathbf{2 0 0 7}^{\mathbf{b}}\end{array}$ & $\begin{array}{l}\text { Follow up } \\
\text { interviews } \\
2009^{\mathrm{c}}, \quad 2014^{\mathrm{d}} \\
2016^{\mathrm{e}}\end{array}$ & $\begin{array}{l}\text { Total } \\
\text { interviews }\end{array}$ \\
\hline \multirow{3}{*}{ Distributors } & \multirow{3}{*}{$\begin{array}{l}\text { Distribution, beverages, } \\
\text { frozen food, wholesale } \\
\text { business, coffee export, } \\
\text { financial services. Latest } \\
\text { business - rehabilitation. }\end{array}$} & \multirow{3}{*}{153} & \multirow{3}{*}{1960} & \multirow{3}{*}{8} & \multirow{3}{*}{2013} & Miles & $1 \mathrm{st}$ & $2^{\mathrm{ab}}$ & $2^{\mathrm{cd}}$ & 4 \\
\hline & & & & & & Julio & $2 \mathrm{nd}$ & $2^{\mathrm{ab}}$ & $3^{\text {cde }}$ & 5 \\
\hline & & & & & & Antonio & $2 \mathrm{nd}$ & $2^{\mathrm{ab}}$ & $3^{\text {cde }}$ & 5 \\
\hline \multirow{3}{*}{ Farmers } & $\begin{array}{l}\text { Large agricultural export } \\
\text { (grains, non-traditional } \\
\text { produce), real estate, }\end{array}$ & \multirow{3}{*}{311} & \multirow{3}{*}{1900} & \multirow{3}{*}{7} & \multirow{3}{*}{2014} & Enrique Sr. & $2 \mathrm{nd}$ & $2^{\mathrm{ab}}$ & $2^{\text {cd }}$ & 4 \\
\hline & $\begin{array}{l}\text { livestock, agricultural } \\
\text { machinery, soy mills, oil }\end{array}$ & & & & & Enrique Jr. & $3 \mathrm{rd}$ & $2^{\mathrm{ab}}$ & $3^{\text {cde }}$ & 5 \\
\hline & $\begin{array}{l}\text { extraction. Latest } \\
\text { business - agro-tourism. }\end{array}$ & & & & & Luis & $3 \mathrm{rd}$ & $2^{\mathrm{ab}}$ & $2^{\text {de }}$ & 4 \\
\hline \multirow{4}{*}{ Landowners } & $\begin{array}{l}\text { Hardware, gas stations, } \\
\text { car replacement parts, }\end{array}$ & \multirow{4}{*}{190} & \multirow{4}{*}{1970} & \multirow{4}{*}{8} & \multirow{4}{*}{2016} & Fernando & $1 \mathrm{st}$ & $2^{\mathrm{ab}}$ & $2^{\mathrm{cd}}$ & 4 \\
\hline & $\begin{array}{l}\text { heavy goods, } \\
\text { transportation and real }\end{array}$ & & & & & Roberto & $2 \mathrm{nd}$ & $2^{\mathrm{ab}}$ & $3^{\text {cde }}$ & 5 \\
\hline & $\begin{array}{l}\text { estate development, } \\
\text { farms, household } \\
\text { appliances. Latest }\end{array}$ & & & & & Miguel & $2 \mathrm{nd}$ & $2^{\mathrm{ab}}$ & $2^{\text {de }}$ & 4 \\
\hline & $\begin{array}{l}\text { business - residential } \\
\text { construction. }\end{array}$ & & & & & Nancy & 2 nd & $2^{a b}$ & $2^{\text {cd }}$ & 4 \\
\hline \multirow{3}{*}{ Transporters } & $\begin{array}{l}\text { Passenger and } \\
\text { commercial }\end{array}$ & \multirow{3}{*}{256} & \multirow{3}{*}{1960} & \multirow{3}{*}{7} & \multirow{3}{*}{2012} & Alberto Jr. & $2 \mathrm{nd}$ & $2^{\mathrm{ab}}$ & $3^{\text {cde }}$ & 5 \\
\hline & $\begin{array}{l}\text { estate, food retail, } \\
\text { express packaging, }\end{array}$ & & & & & Pedro & 2nd & $2^{\mathrm{ab}}$ & $2^{\text {cd }}$ & 4 \\
\hline & $\begin{array}{l}\text { construction. Latest } \\
\text { business - cattle farming. }\end{array}$ & & & & & Gerardo & 2nd & $2^{\mathrm{ab}}$ & $2^{\text {de }}$ & 4 \\
\hline
\end{tabular}


Table 2. Sources and objects in metaphors by families in business (based on Dodd, 2002)

\begin{tabular}{|c|c|c|c|c|c|c|c|}
\hline Background & Vehicles & Grounds & & & & & Explanation \\
\hline Distributors & $\begin{array}{l}\text { Connecting } \\
\text { the dots }\end{array}$ & $\begin{array}{l}\text { Interpreting } \\
\text { entrepreneurial } \\
\text { opportunities } \\
\text { starts with a } \\
\text { blank sheet of } \\
\text { paper and } \\
\text { 'dots' without } \\
\text { a clear picture. }\end{array}$ & $\begin{array}{l}\text { Every 'drawing' } \\
\text { has diverse } \\
\text { features/challenges, } \\
\text { interconnections } \\
\text { between 'dots' } \\
\text { need interpretation. }\end{array}$ & $\begin{array}{l}\text { Connecting } \\
\text { 'dots' is } \\
\text { achieved with } \\
\text { and through } \\
\text { others (family, } \\
\text { nonfamily). }\end{array}$ & $\begin{array}{l}\text { Interpretation } \\
\text { of drawings } \\
\text { may change } \\
\text { through } \\
\text { interactions } \\
\text { over time. }\end{array}$ & $\begin{array}{l}\text { Picture } \\
\text { (opportunity) } \\
\text { becomes } \\
\text { clearer as 'dots' } \\
\text { are connected } \\
\text { and the content } \\
\text { is discussed and } \\
\text { agreed. }\end{array}$ & $\begin{array}{l}\text { Metaphor associates dot-to-dot } \\
\text { drawings with understanding } \\
\text { opportunities. The entrepreneurial } \\
\text { process is highly interconnected. Dots } \\
\text { represent resources, information, and } \\
\text { people that can be linked through } \\
\text { knowledge and information. A clearer } \\
\text { drawing, representing a constructed } \\
\text { opportunity, will emerge and expand } \\
\text { as dots are visualised and connected. }\end{array}$ \\
\hline Farmers & $\begin{array}{l}\text { Sowing and } \\
\text { harvesting }\end{array}$ & $\begin{array}{l}\text { Interpreting } \\
\text { entrepreneurial } \\
\text { opportunities } \\
\text { reflects a } \\
\text { process } \\
\text { dependent on } \\
\text { nature } \\
\text { (environment) } \\
\text { and people. }\end{array}$ & $\begin{array}{l}\text { Every 'field' } \\
\text { needs resources, } \\
\text { hard work, and } \\
\text { persistence, yet } \\
\text { with limited } \\
\text { control of the final } \\
\text { outcome. }\end{array}$ & $\begin{array}{l}\text { Overcoming } \\
\text { setbacks can be } \\
\text { achieved with } \\
\text { the support of } \\
\text { others inside or } \\
\text { outside family } \\
\text { circles. }\end{array}$ & $\begin{array}{l}\text { The harvest } \\
\text { depends on } \\
\text { what the } \\
\text { family knows, } \\
\text { the } \\
\text { environment, } \\
\text { what they } \\
\text { 'sow', chance } \\
\text { and patience. }\end{array}$ & $\begin{array}{l}\text { Sowing and } \\
\text { harvesting } \\
\text { represent } \\
\text { natural cycles } \\
\text { that can be } \\
\text { engaged time } \\
\text { and time again } \\
\text { (nature of } \\
\text { agriculture). }\end{array}$ & $\begin{array}{l}\text { Metaphor associates the language of } \\
\text { traditional farming and new crops } \\
\text { with understanding opportunities. It } \\
\text { relates to a natural progression where } \\
\text { members plan diligently, sow and } \\
\text { harvest based on schedules contingent } \\
\text { on climate and weather. Opportunities } \\
\text { are interpreted as engagement in a } \\
\text { natural cycle. }\end{array}$ \\
\hline Landowners & Playing a game & $\begin{array}{l}\text { Interpreting } \\
\text { entrepreneurial } \\
\text { opportunities } \\
\text { resembles } \\
\text { playing a } \\
\text { board game } \\
\text { with the } \\
\text { family. }\end{array}$ & $\begin{array}{l}\text { Every 'game' has } \\
\text { rules that need to } \\
\text { be understood first, } \\
\text { several people are } \\
\text { involved with } \\
\text { resources at hand. }\end{array}$ & $\begin{array}{l}\text { The outcome of } \\
\text { the game is } \\
\text { uncertain every } \\
\text { time it is } \\
\text { played, risks } \\
\text { and rewards are } \\
\text { involved. }\end{array}$ & $\begin{array}{l}\text { As there are } \\
\text { limited } \\
\text { resources/time, } \\
\text { guidance } \\
\text { through others } \\
\text { is needed. }\end{array}$ & $\begin{array}{l}\text { The more the } \\
\text { game is played, } \\
\text { the more room } \\
\text { for adaptation } \\
\text { and improved } \\
\text { decision- } \\
\text { making. }\end{array}$ & $\begin{array}{l}\text { Metaphor associates playing a game } \\
\text { with understanding opportunities. } \\
\text { Knowing the rules (contextual } \\
\text { aspects), resources and time, allow } \\
\text { family members to engage in the } \\
\text { game as they play, making decisions } \\
\text { as the process unfolds about resources } \\
\text { supported by others. }\end{array}$ \\
\hline Transporters & $\begin{array}{l}\text { Being on the } \\
\text { road }\end{array}$ & $\begin{array}{l}\text { Interpreting } \\
\text { entrepreneurial } \\
\text { opportunities } \\
\text { represents a } \\
\text { journey with } \\
\text { family through } \\
\text { uncharted } \\
\text { territories. }\end{array}$ & $\begin{array}{l}\text { Every 'journey' } \\
\text { may be planned in } \\
\text { advance, with a } \\
\text { defined starting } \\
\text { point, route, and } \\
\text { destination. }\end{array}$ & $\begin{array}{l}\text { Unexpected } \\
\text { setbacks (turns, } \\
\text { hills) are to be } \\
\text { expected, } \\
\text { which impact } \\
\text { the resources } \\
\text { used. }\end{array}$ & $\begin{array}{l}\text { When lost on } \\
\text { the road or } \\
\text { considering } \\
\text { alternative } \\
\text { destinations, } \\
\text { help from } \\
\text { others can help } \\
\text { get back on } \\
\text { track. }\end{array}$ & $\begin{array}{l}\text { Every journey } \\
\text { is different, } \\
\text { detours and } \\
\text { setbacks in the } \\
\text { journey can } \\
\text { lead to great } \\
\text { destinations. }\end{array}$ & $\begin{array}{l}\text { Metaphor associates understanding } \\
\text { opportunities as a journey, with } \\
\text { haphazard and emergent processes. } \\
\text { Opportunities embody shared } \\
\text { understanding of an accompanied } \\
\text { development that will entail change } \\
\text { and chance. }\end{array}$ \\
\hline
\end{tabular}


Table 3. Understanding opportunities through metaphors (guided by Konopaski et al. 2015)

\begin{abstract}
Empirical data
Julio: ... after my mom passed away 'connecting dots' had a strong meaning for us ... I'd need to know a bit about every 'dot' in the map where I can distribute

[products] ... what is the profile of customers who live there? What prices can I charge? How am I going to get products there at the minimum costs? ... That is a simple way of doing things but it works for us regardless of whether we studied medicine, law, or anything else. (Distributors, June 2009)
\end{abstract}

Alberto Jr: ...My Dad made sure we all had that experience [being on the road] and even though we all studied different things, we all relate to it. It is stuck in our memories forever. So now we do the same with our children, we still have the original business [passenger transport] and of course modern fleets but the thinking remains the same. They [new generations] also have to go and experience that [being on the road]. It is a way to honour our Dad's legacy. (Transporters, May 2007)

Enrique Jr: ...We [junior generation] all had to sow a crop or plant a tree, look after it, check the best way to make it grow, harvest it, and sell it. So when my Dad talked to us about starting a new business being like planting a new crop, then I can see it in my mind easier than if he said something else.... My brothers will tell you the same thing. (Farmers, August 2014)

Gerardo:... for us, it was as simple as recalling 'being on the road', every bit was connected: from the people that could drive the transport vehicle, knowing the best routes that can get you from here to there, to knowing how much weight the vehicle can carry ... because we had used it ['being on the road' metaphor] before when looking at the fast food opportunity with Dad, it made sense again. (Transporters, August 2014)

\section{Description}

Succeeding generation relates

earlier experiences of 'connecting

dots' to constructing opportunities.

Emotional links to deceased parent

guidance increased its appreciation.

Succeeding generation articulates that 'being on the road' is shaped by early experiences. Social situations like in being in a bus with family members can shape a metaphorical approach in future generations. Early communication from deceased parent increased shared understanding.

Succeeding generation highlights connection to early interactions and experience to agricultural language and 'sowing and harvesting' to interpret opportunities.

Succeeding generations compare new opportunities outside existing sectors to meanings communicated repeatedly through the 'being on the road' metaphor.
Thematic

Early shared experiences

influenced the

(re)interpretation of

previous and new

opportunities after

critical events.

Early interaction

influences a shared metaphorical approach

among diverse members.

Early shared experiences

lead to shared

understanding and

communication about a

metaphor based on the

physical world.

Continuous family

communication allows

shared views about the

connection of a metaphor

to interpreting new

opportunities. interpret opportunities

can be shaped by early

interactions, critical

events (sudden death), and family social

situations.

Thematic

Communication from

an early age allows

developing common

understandings about

epreneurial

pportunities, which

remain imprinted after

family members are no

longer around.

Metaphors may only be interpreted by those who have engaged early and continuously

in business activities.

Shared views of the meaning of a metaphor allows comparing

different domains over time.
Theoretical implication

Metaphorical vehicles are introduced based on early years' interaction:

Communication and shared interpretations of opportunities.
Metaphorical approach to family

entrepreneurship: comparisons and connections.

Shared views, collaboration, and continued communication. 
Fernando: ...I think because they [junior generation] see starting a firm as playing our game [monopoly], then it is easier to make sense of it for the future... when the home appliances business was first being discussed, they were able to highlight what location would be best based on the properties we owned, what were the problems along the way, and of course suggesting how they could also invest together if a particular location was chosen... I imagine they would do that again when a new business idea comes about. (Landowners, June 2009)

Enrique Sr: ...so now I have grandchildren, most of them want to be involved in the farm and tell me about their ideas... they need to learn more about our stories and be involved in the fields... their parents know that they have to use the same examples [metaphor] I did, even if they have new firms, it will bind them together, the same way my father did with me... (Farmers, January 2016)

Julio: ...I still keep some of those [dot-to-dot] drawings to remind me about what mom taught me about how to start a firm... we just recently started a new rehabilitation clinic project as my brother was studying medicine when mom died. It was easy for us to sit down, even after al that time that we had not really talked about the project and start 'connecting dots'... it was a time for us to remember our mom and also realise how important making sense of it [connecting dots] is for us.

(Distributors, August 2014)

Gerardo: We all have different memories of Dad, but we all share one thing, we 'were on the road' with him, that is what binds us since we were kids. We were all interested in different stuff, but the way we learned about doing business based on that [metaphor] allowed us to create new ones even if they have nothing to do with transportation.... we know what that [being on the road] means for us and few people will understand it. I can tell you about it but that connection is missing if you have not done it with us. (Transporters, January 2016)
Incumbent generation articulates the way in which offspring use the 'playing a game' metaphor, specifying how a metaphor allows interpreting opportunities.

Good intra-family relationships support continued communication about the 'sowing and harvesting' metaphor for new generations.

Articulating the ways by which 'connecting dots' unites family members after the death of a business founder.

Articulating the way that 'being on the road' bonds members through shared experiences and excludes others of the meanings embedded.

Relevance of communication of a metaphor by family members to strengthen bonds and create a social unit. about the meaning of a metaphor and its meaning when creating new opportunities.
Family bonds lead to engagement with ounger generations to communicate and pass on a metaphorical approach.

Shared views about metaphors allow reinforcing the social unit in business.

Repeated communication Interpreting opportunities based on collective comparisons through a shared metaphor.

Interpretation of opportunities through metaphors strengthen relationships through shared experiences across generations.

Communicating metaphor and its emotional link is appreciated by selected family members.

Metaphorical

approach:

Implications for exclusion) over time.
Shared views around a metaphor include unique understanding only experienced by family members. 
Enrique Jr: ... it is 'sowing and harvesting' for us... it does not matter if I studied marketing and my brother engineering, we can all relate back to it... we know what it means... it is different with our cousins, who live in the city and their parents have no farm, they come to visit us during their vacations for a few weeks... I do not think they will ever get it. (Farmers, June 2009)
Articulating how meanings embedded in 'sowing and

harvesting' around opportunities can only be understood by those

sharing experiences in business.
Communicating

metaphors in particular settings allows

reinforcing a shared

identity.
Metaphors may only be

interpreted by those who continue to be involved in business activities as family over time. 
